\title{
Migrant Farm Worker
}

National Cancer Institute

\section{Source}

National Cancer Institute. Migrant Farm Worker. NCI Thesaurus. Code C85877.

A worker who travels from place to place as an agricultural worker, ususally moving to participate in harvest activities. 